Yll: 2021, Cilt: 54, Sayl: 3, 721-746

DOI: 10.30964/auebfd.875732, E-ISSN: 2458-8342, P-ISSN: 1301-3718

\title{
Sınıf Öğretmenlerinin Öğrenciler Arası Rekabete İlişkin Görüşleri ${ }^{1}$
}

\begin{tabular}{lccc}
\hline MAKALE TÜRÜ & Başvuru Tarihi & Kabul Tarihi & Yayım Tarihi \\
Araştırma Makalesi & 08.02 .2021 & 21.08 .2021 & 07.10 .2021 \\
\hline
\end{tabular}

\author{
Merve Kurumanoğlu (iD) 2 \\ Milli Eğitim Bakanlığı \\ Naciye Aksoy \\ Gazi Üniversitesi
}

Öz

Eğitim öğretim uygulamalarında rekabetin öğrenciler üzerindeki etkileri hakkında sınıf öğretmenlerinin görüşlerini belirlemek amacıyla gerçekleştirilen bu araştırmada öğretmenlerin görüşleri; cinsiyetlerine, hizmet sürelerine, görev yaptıkları okul türlerine (devlet-özel), mezuniyet durumlarına (lisans-lisansüstü) ve okuttukları sınıf düzeyine göre incelenmiştir. Araştırma; nicel araştırma yaklaşımına göre tasarlanmış olup betimsel tarama modelinde gerçekleştirilmiştir. Ankara ili Yenimahalle ilçesindeki özel ve devlet ilkokullarında görev yapan 325 sınıf öğretmeni araştırmanın örneklemini oluşmaktadır. Veriler, araştırmacılar tarafindan geliştirilen, uzman görüşüne göre düzenlenen ve örneklemde yer almayan 130 sınıf öğretmeni ile pilot uygulaması ve geçerlik güvenirlik çalışması yapılan Likert tipi ölçek formu ile elde edilmiştir. Araştırmaya katılan öğretmenler, öğrenciler arası rekabete ilişkin yargıların büyük kısmına orta düzeyde, rekabetin öğrencilerde yaratacağı olumsuz psiko-sosyal (kıskançlık, stres, kaygı, baskı, olumsuz benlik saygısı) etkilere yönelik yargılara ise ortanın üstünde katılmaktadır. Özel okulda çalışan öğretmenler rekabetin öğrenciler üzerinde yaratacağı olumsuz duygusal/ruhsal etkilerine, devlet okulunda çalışan öğretmenler ise rekabetin eğitim-öğretim sürecindeki olumlu etkilerine daha çok katılım göstermektedir. On yıla kadar mesleki kıdeme sahip olan öğretmenlerin rekabetin öğrencide yaratacağı olumsuz etkilere katılma düzeyleri 21-46 yıl kıdeme sahip öğretmenlerden daha yüksektir. Cinsiyet, mezuniyet durumu ve okutulan sınıf düzeyleri de öğretmenlerin öğrenciler arası rekabete ilişkin bazı yargılara katılma durumlarında belirleyicidir.

Anahtar sözcükler: Öğrenciler arası rekabet, ilkokul, sınıf öğretmeni, neoliberalizm, rekabetçi eğitim sistemi.

Etik kurul kararı: Bu araştırma, 01.01.2020 tarihinden önce yapıldığı için etik kurul kararı zorunluluğu taşımamaktadır.

${ }^{1}$ Bu makale birinci yazarın ikinci yazarın danışmanlığında Gazi Üniversitesi Eğitim Bilimleri Enstitüsü’nde 2019 y1lında tamamlanan yüksek lisans tezinden türetilmiștir.
${ }^{2}$ Sorumlu
Yazar:
M.E.B.
Sinif
Öğretmeni.
e-posta:

mervekurumanoglu.12@gmail.com,https://orcid.org/0000-0003-4421-293X

${ }^{3}$ Prof. Dr. Gazi Üniversitesi, Gazi Eğitim Fakültesi, Temel Eğitim Bölümü, Sınıf Eğitimi Anabilim Dalı, eposta: naciye@gazi.edu.tr, https://orcid.org/0000-0002-3136-6473 
Ülkelerin eğitim sistemleri, içinde bulundukları toplumsal, tarihsel, ekonomik, kültürel, politik yapılara göre biçimlendirilir. Türk Eğitim Sistemi Cumhuriyetin ilk yıllarında ilerlemeci bir felsefenin etkisi altına girmiş; eğitimde bireycilik, verimli çalışma, demokratik katılım gibi kavramlar ön plana çıkmıştır (Erkılıç, 2013). İlerleyen dönemde önemli reformlardan biri olarak görülen "köy enstitüleri" ise eğitim sistemine toplumcu bir anlayış getirmiștir (Sözer, 2008 s. 67). Köy enstitülerinin kapatılmasıyla Türk eğitim sistemi tekrar esasici ve daimici akımların etkisi altına girmiştir (Sönmez, 2019).

Türkiye'de köklü değişimlerin yaşandığı 1980'li yıllarda küreselleşmenin öne çıkardığı neoliberal politikalar bilim ve kültürün metalaşmasına yol açmış, bu durum eğitim sisteminin amacını ve işlevini değiştirmiştir (Okçabol, 2007). Eğitim süreçleri neoliberal ekonomi politikaları altında ticarileştirilen ve piyasalaştırılan okullar (özel okul) saygınlık (itibar) kazanmış, öğretmen, öğrenci, yönetici ve veli rolleri değişmiştir. $\mathrm{Bu}$ süreçte bilginin inşası ve anlamı da piyasalaşmanın etkisi altına girmiş, kamusal eğitim anlayışı ve eşitlikçi eğitim kavramlarına uzak, kişisel çıkar ve piyasa kavramlarına dayalı bir eğitim sistemi baş göstermiş̧ir (Aksoy, Deniz ve Algan, 2017). Rekabet, eğitim sistemini belirleyen etmenlerden biri durumuna gelmiş̧ir. Eğitim sistemi içindeki öğrenciden, veliye ve hatta öğretmenine kadar herkes birbiriyle rekabete yönelmiştir (Keskin, 2012). Eğitimdeki rekabetçi anlayış eğitimle ilgili yasalara da yansımıştır. 2011'de düzenlenen 652 Sayılı Kanun Hükmünde Kararname 2018'de 1 Sayılı "Cumhurbaşkanlığı Teşkilatı Hakkında Cumhurbaşkanlığı Kararnamesi” altında güncellenmiştir. Bu kararnamede Milli Eğitim Bakanlığının görevleri, 301. maddenin a bendinde aşağıdaki gibi belirtilmiştir (Cumhurbaşkanlığı Teşkilatı Hakkında Cumhurbaşkanlı̆̆g Kararnamesi, 2018):

Okul öncesi, ilk ve orta öğretim çağındaki öğrencileri bedenî, zihnî, ahlakî, manevî, sosyal ve kültürel nitelikler yönünden geliştiren ve insan haklarına dayalı toplum yapısının ve küresel düzeyde rekabet gücüne sahip ekonomik sistemin gerektirdiği bilgi ve becerilerle donatarak geleceğe hazırlayan eğitim ve öğretim programlarını tasarlamak, uygulamak, güncellemek; öğretmen ve öğrencilerin eğitim ve öğretim hizmetlerini bu çerçevede yürütmek ve denetlemek.

Kararnamede geçen "küresel düzeyde rekabet gücüne sahip ekonomik sistemin gerektirdiği bilgi ve becerilerle donatarak..." ifadesi rekabetçi eğitim ve girişimcilik kavramlarını ön plana çıkarıp eğitim-öğretim anlayış ve uygulamalarının daha çok sınav odaklı yürütülmesine resmiyet kazandırmıştır. Elemeye dayalı sınav sistemi sadece sınav rekabetini değil, sınıf içi pratiklerde de "yıkıcı rekabeti" beraberinde getirmiştir. Öğrencilerin, notlarını sene sonunda hazırlandıkları sınava hizmet ettiği için gereğinden fazla önemsemeleri, okullarda sonuç odaklı ve rekabetçi anlayışı yüceltmiştir. Sınavlar iş, eğitim ve gündelik yaşamı belirleyen/düzenleyen, yaşama Sosyal Darwinist açıdan bakmaya yol açan bir ideoloji (İnal, 2008), eğitimin kendisinden daha çok ilgi çeken bir öge haline gelmiştir (Aksoy ve diğ., 2017). Merkezi sınav günlerine yaklaşırken arka sıralarda test çözmek ve dersanelerde sırf 
daha fazla test çözebilmek için okulun öğretim programından uzaklaşmak için alınan heyet raporları günümüzün gerçeği durumuna gelmiştir. Bu sınavlara çalışmak için yapılan fedakarlıklar çocukları ve gençleri fiziksel, bilişsel, ruhsal, yönlerden çöküntüye uğratmaktadır.

Campbell ve Twenge'in (2010) (akt., Yılmaz, 2014) çalışmasında rekabetçi ve düzey belirleyici eğitim sisteminin öğrencilerin empati duygusunu ortadan kaldırarak narsistik kişilik özelliklerini şişirdiğini belirtmiştir. İnsanları sınıflayan bu zemin doğrudan insan ilişkilerine de yansımaktadır. Okul sisteminin ortaya koyduğu bu "düzeyler" diğerini dinlemeyi, anlamayı, acılarına ortak olma duygusunu yok ederken narsisizmi, kibiri, üstünlüğü, bencilliğì, ayrıcalıklığı kamçılamıştır. Sadece "kazanmaya" odaklanmak insan ilişkilerini de bozmuştur.

Rekabet ve rekabetçilik kavramları üzerinde birtakım tanımlar mevcuttur. Rekabet, "Aynı amacı güden kimseler arasındaki çekişme, yarışma, yarış” olarak tanımlanmaktadır (Türk Dil Kurumu [TDK], 2019). En geniş tanımıyla insanlar arası rekabet, iki ya da daha fazla insanın paylaşılamayacak bir hedef için çabaladığı, genellikle bir galip ve kaybedenle sonuçlanan bir yarışmadır. Rekabetin önemli iki öğesi; ortak bir hedefin olması ve kazanan ve kaybedenle sonuçlanmasıdır (Cantador ve Conde, 2010). Akademik ve sosyal yaşamın iç içe geçtiği okul ortamında birinin en iyi arkadaşı olmaktan, sınıf içi, ders dışı ve sportif etkinliklere kadar pek çok durumda öğrenciler arası rekabet yaşanmaktadır (Heinrich, 2014). Ancak eğitim kuramcıları ve psikologlar rekabetin üstünlük (avantaj) ve sinırlılıkları (dezavantajları) konusunda farklı görüşler ortaya koymaktadırlar. Kuramsal temelde ilk köklü çalışmayı Horney yapmıştır. Horney (1997, s. 164) rekabetin insanları nevrotik bir kişiliğe büründürdüğünü, bu durumun herkes için bir sorun oluşturduğunu ve nevrotik kişiliğin oluşmasında çok etkili olduğunu belirtmektedir. Nevrotik birey, saygınlık (prestij) ve güç kazanmak için başarılı olmaya yönelmekte, büyük bir hırsla her alanda en üstün ve eşsiz olmaya çalışmakta, başkalarının kendisinden daha başarılı olmasını hazmedememekte, hırsı ile ilgili rakiplerine karşı düşmanlık beslemektedir. Nevrotiğin başarısı rakiplerinin başarısızlığı ve ezilmesiyle doğru orantılıdır. Bazen de rakibi karşısında kazanamama düşüncesi onu aşağılanma ve küçük düşme korkusuna kaptırmaktadır. Bu nedenle çoğu zaman yarışma içine girmemekte ve rekabetten çekilmeyi tercih etmektedir. Bolat (2009), "Rekabet çocukları nasıl etkiliyor?" başlıklı yazısında rekabetin uzun vadede çocuklara zarar verdiğini belirtmektedir. Rekabet öğrenmeyi ve kendini geliştirmeyi değil, sıralamadaki dereceyi önemsemektedir. Rekabetin en kötü etkisi de çocukların özgüvenini azaltmasıdır. Çocuk özgüveni kazanmayla ilişkilendirdiği zaman, kendine olan güvenini kaybetmemek için sürekli yarışma kazanmak zorunda hissetmektedir. Eğer rekabet ortamı riskliyse o ortama girmemeyi tercih etmekte ve "tembel olursam yarışıyor olmam” düşüncesine kapılarak öğrenmeyi reddetmektedir. Rekabet ortamında kazanmak, her zaman diğerlerinin kaybetmesine bağlıdır. Bu nedenle bireyler arası ilişkiler zayıflamaktadır. Bu durum da işbirliği ve paylaşımları olumsuz etkilemektedir. 
Kohn'a göre (1992, s. 8), rekabet çeşitli efsaneler üzerine temellendirilmiştir. Rekabetin insan doğasının bir parçası olduğu için kaçınılmaz olması bir efsanedir. Öğrenciler yapay rekabetçi dünyaya hazırlanmaktadır. Oysa insan toplumunun büyük çoğunluğu rekabet gücüne değil işbirliğine dayalı etkileşim gücüne sahiptir ve bu işbirliği ile yaşamda kalmaktadır. Rekabetin iyi zaman geçirmenin tek yolu olması diğer efsanedir. Bu nedenle oyun oynamanın tüm zevkinin rekabete dayalı olmasından kaynaklandığı söylenir. Efsanelerden bir diğeri de rekabetin insanı elinden gelenin en iyisini yapmaya güdülediği, rekabet etmezse üretken olmayı bırakacağı düşüncesidir ki bu varsayıma okul notlarından kapitalizme kadar herşey için başvurulur. Öğrenci okul performansını bir yarış olarak gördüğünde çaresiz bir kalıp geliştirmektedir. Başlangıçta güdülendiklerini zannetseler de sonrasında iç güdülenmenin (motivasyonun) azalmasına, hedeflerin küçülmesi ve azalmasına, zor durumlara karşı direncin kırılmasına ve en sonunda da pes etmelerine neden olmaktadır. Bu durum süreçten ürüne odaklanma (öğrenmeyi azaltma), başarısızlık korkusu ve iç güdülenmenin baltalanmasını ortaya çıkarmaktadır (Shindler, 2009). Dördüncü efsane ise rekabetin özgüven ve kişiliğe olumlu katkılarının olması iddia ve inançlarıdır. Son araştırmalar da bu tezi çürütmektedir (Kohn, 1992). Öğrenciler normlara göre derecelendirildiklerinden akranlarından daha hızlı ve daha doğru yapmaya zorunlu bırakılmaktadır. Sınıf arkadaşları ile yapılan bu rekabette "Kazancım senin kaybettiğin anlamına gelir" düşüncesi ile başkalarını mahrum etmektedirler. "Başarısızlığın benim kazanmamı kolaylaştırır" düşüncesi ile arkadaşlarının başarısızlığını kutlamaktadırlar. "Ne kadar kazanırsan benim için o kadar kötü; ne kadar başarısız olursan benim için o kadar iyi” düşüncesi ile olumsuz ilişkilerini pekiştirmektedirler (Johnson ve Johnson, 2017). Ayrıca bir çocuğun dikkati kazanmaya veya kaybetmeye odaklandığında, çocuğa sosyal ve yaşam becerilerini öğretmek giderek zorlaşmaktadır (Mincemoyer, 1994). Araştırmalar göstermektedir ki son yıllarda Batı toplumlarında yoğun rekabet gücünün artması ile kaygı, depresyon, kendine zarar verme davranışları paralellik göstermektedir. Rekabetçi davranışın değerini vurgulayan toplumların, rekabetin karanlık yüzüne (aşağılık duygusu, reddedilme korkusu, göz ardı edilme, depresyon, endişe, stres) dikkat etmeleri yönünde araştırmalar da bulunmaktadır (Gilbert, McEwan, Bellew, Mills ve Gale, ., 2009).

Clifford (1989) rekabetin çocuklar üzerindeki olumsuz etkilerini şu şekilde özetlemektedir:

1. Rekabet, dikkat dağıtıcı olabilmekte ve yoğunlaşmayı azaltabilmektedir.

2. Rekabet, ters tepkiyi -ihtiyacı olan arkadaşa sırf rakip olduğu için yardım etmemek gibi- özendirebilmektedir.

3. Rekabet, dengesiz beceri gelişimine yol açabilmektedir.

4. Rekabet, hatalı benlik algisina neden olabilmektedir. Rekabet eden ve genellikle başarısız olan gençler kendileri hakkında olumsuz yargılara sahip olabilmektedir. 
5. Rekabet, bireylerin yetenekleri hakkında yanlış yargılara yol açabilmektedir. Rekabetçi durumlardan kaygı duyan gençler becerilerinin altında başarım (performans) gösterebilirler.

6. Rekabet, hile ve adaletsiz uygulamalara yol açabilmektedir.

Ediger'e göre (2001) ise rekabet sağlıklı da yıkıcı da olabilmektedir. Sağlıklı rekabette birey potansiyelinin en üst düzeyine çıkabilmektedir. Çaba, azim ve kararlılıkta olumlu performans gösterilebilmekte, rekabet eğlenceli ve ilgi çekici olabilmektedir. Sağlıklı bir rekabette rakipler eş değer beceri ve kapasitede olmalı, diğerlerine karşı olumlu tutum geliştirmeli, öğrenme arzusunda olmaları ve bütün bireylerin kazanan olamayacağını bilmeleri gerekmektedir. Rekabet düşmanlık geliştirmemeli, öğrencileri hedeflerinden saptırmamalı, yetenek ve ilgi alanları yönünden iyi olmayan öğrencileri karşılaştırmamalı, öğrencilerin öğrenme stillerine uyumlu olmalı ve başarılarını artırmalıdır. Shindler (2009), rekabetin ancak oyunlaştırıldığı ve eğlenmek için yapıldığı zaman öğrenmenin kalıcılığını sağladığı ve özsaygıyı geliştirdiğini belirtmektedir. Rekabetin güçlü bir destekçisi olan Verhoeff (1997) de öğrenciler arasında iyi düzenlenmiş bir rekabetin eğitimde hemen hemen her disiplinde yararlı olduğunu, öğrencileri en iyisini yapmaya zorladığ 1 için de güdülenmeyi ve öğrenmeyi artırdığını ileri sürmektedir. Rekabetin yararlı olabilmesi için, katılımcılar ellerinden gelenin en iyisini yapmaya zorlanmalıdır. Aynı zamanda rekabetin kuralları olması, şeffaf ve eksiksiz hazırlanması gerekmektedir. Sağlıklı bir rekabet için bazı konuların dikkate alınması gerektiği belirtilmektedir (Cantador ve Conde, 2010; Cantador ve Bellogin, 2012): Birincisi, öğrencilerin çabalarının içsel olduğundan emin olmak için kazananlara verilen ödüller ya simgesel (sembolik) olmalı ya da çok az öneme sahip olmalıdır. İkincisi, rekabet kısa olmalıdır. Rekabet süresinin uzunluğu, her ikisi de istenmeyen etkiler olan, öne çıkma duygusunu artırırken yoğunluk ve eğlence duygusunu azaltır. Öte yandan, rekabet, öğrencinin güdülenmesinin düşmesini önlemek ve tüm katılımcıların etkinliğin sonuna kadar kazanma şansının yüksek olmasını sağlamak için yeterince uzun olmalıdır. Son olarak rekabetin amacı, sonuçlara değil sürece oturtulmalı ve kazanmanın veya kaybetmenin, rekabet sırasında öğrenmeye ve geliştirmeye göre çok düşük önemde olduğu açıkça ortaya konulmalıdır. Bu konulardan başka Cantador ve Bellogin (2012) takımlar arası rekabetin öğrenciler için daha az zararlı olduğu ve öğrenme becerilerini etkili bir şekilde geliştirebileceği konusunda daha genel bir fikir birliğinin var olduğunu da belirtmektedirler. Ayrıca takımlar arası rekabette öğrenciler, takımlarının iyiliği için sorumluluklarını ve görevlerini daha iyi yerine getirmektedir (Thousand, Villa ve Nevin, 1994).

Rekabet konusunda yapılan araştırmalar (örneğin Skon, Johnson ve Johnson, 1981; Johnson, Maruyama, Johnson, Nelson ve Skon,1981; Johnson ve Johnson, 1982; Johnson ve Johnson,1985; Johnson, Johnson ve Stanne, 1985; Ladd ve Fiske, 2003; Kalowole, 2007; Hilk, 2013; Zhao, 2015) genel olarak öğrencilerin rekabetçi ortamlara göre işbirlikçi ortamlarda daha başarıll, sosyal, benlik saygısı gelişmiş ve ruhsal yönden dengeli olduklarını, daha yüksek başarı, bilgi, yeterlik ve sorun çözme becerisi gösterdiklerini ortaya koymaktadır. Gilbert ve diğ., (2009) araştırmalarında 
rekabetçi davranışların kaygı, stres, kendine zarar verme davranışlarıyla ilintili olduğunu belirtmiştir. Ulusal alanyazında da eğitimde rekabet kavramını farklı değişkenler üzerinden ve ölçek geliştirme açısından ele alan çeşitli araştırmalar (Akbayırl1, 1998; Yenidünya, 2005; Köroğlu, 2008; Üresin, 2012; Malkoç ve Erginsoy, 2012) bulunmaktadır. Ancak okullarda öğrenciler arası rekabete ilişkin öğretmen görüşlerini doğrudan ele alan bir araştırmaya alanyazında rastlanmamıştır. $\mathrm{Bu}$ araştırmalar ve kavramsal temellendirmelerden hareketle bu araştırmada devlet ilkokulları ve özel ilkokullarda görev yapan sınıf öğretmenlerinin öğrenciler arası rekabete ilişkin bakış açıları belirlenmeye çalışılmaktadır. Bu genel amaca dayalı olarak araştırmada şu sorulara yanıt aranmaktadır:

1. Sınıf öğretmenlerinin öğrenciler arası rekabete ilişkin görüşleri nasıldır?

2. Sınıf öğretmenlerinin öğrenciler arası rekabete ilişkin görüşleri;

a. Cinsiyetlerine,

b. Kıdemlerine (hizmet sürelerine),

c. Görev yaptıkları okul türüne (devlet okulu, özel okul),

d. Eğitim durumlarına (lisans, lisansüstü),

e. Okuttukları sınıf düzeylerine göre değiş̧mekte midir?

Kavramsal çerçevede açıklandığı üzere rekabetin olumlu ve olumsuz etkileri nedeniyle üzerinde bir uzlaşı söz konusu değildir. Ancak araştırmalar eğitim öğretim süreç ve uygulamalarında rekabetin yıkıcı sonuçlara yol açtığını ortaya koymaktadır. Türk Eğitim sisteminde de rekabet vazgeçilemez bir gerçeklik durumuna gelmiştir. $\mathrm{Bu}$ gerçekliğe yönelik şikayetler/kaygılar sendikalar, akademisyenler, aileler, öğrenciler ve öğretmenler tarafından sürekli dile getirilmesine karşın konuya ilişkin yapılan araştırma sayısı oldukça sınırlıdır. Oysa toplumsal bir sorunun sağlıklı bir şekilde çözülebilmesi ancak konuya taraf olanların katılımına dayalı bilimsel verilerle olanaklıdır. Buradan hareketle eğitim sisteminin en önemli bileşeni olan öğretmenlerin öğrenciler arası rekabete ilişkin görüşlerinin alınmasının alana önemli katk1 sunacağı düşünülmektedir. Düşüncelerin davranışları etkilediği düşünüldüğünde, bu araştırmanın sonuçlarının dolaylı olarak öğretmenlerin sınıf içi uygulamalarında öğrenciler arası rekabeti hangi açılardan desteklediklerinin ya da desteklemediklerinin de ipuçlarını vermesi beklenmektedir. Ayrıca araştırmanın gerek kavramsal temelleri gerekse sonuçları bakımından eğitim politikacılarına, eğitim bilimcilere, öğretmen eğitimcilerine, öğretmenlere ve ailelere de okullarda açık ve örtük yollarla kazandırılan rekabetçi ve işbirlikçi değer ve davranışların değerlendirilmesinde bir bakış açısı sunabilmesi umulmaktadır.

\section{Yöntem}

$\mathrm{Bu}$ bölümde araştırmanın modeli, evren ve örneklem, verilerin toplanması, geçerlik-güvenirlik çalışmaları ve verilerin analizine yer verilmiştir. 


\section{Araştırma Modeli}

$\mathrm{Bu}$ araştırma, nicel araştırma olarak tasarlanmış ve betimsel tarama modeline göre gerçekleştirilmiştir. Örneklemde yer alan sınıf öğretmenlerinin öğrenciler arası rekabete ilişkin görüşleri var olduğu şekliyle betimlenmiş olup öğretmenlerin görüşlerine hiçbir şekilde müdahalede bulunulmamıştır. Öğretmenlerin öğrenciler arası rekabete ilişkin görüşlerinin cinsiyet, kıdem, okul türü, sınıf düzeyi, eğitim durumuna göre değişip değişmediği de tekil tarama yoluyla incelenmiştir.

\section{Evren-Örneklem}

Araştırmada 2017-2018 eğitim öğretim yılında Ankara ili Yenimahalle ilçesinde bulunan devlet ilkokulları ve özel ilkokullar ulaşılabilir evren olarak tanımlanmıştır. $\mathrm{Bu}$ çerçevede, Yenimahalle İlçe Milli Eğitim Müdürlüğü verileri esas alınarak evrende 56 devlet ve 37 özel olmak üzere 93 ilkokul bulunduğu ve bu okullarda da 2,633 sınıf öğretmeninin görev yaptığı belirlenmiştir. 3.000 kişilik bir evren büyüklüğünden .95 güven aralığında, .05 tolere edilebilir sapma miktarı ile 341 kişinin yeterli olabileceğini gösteren uygun örneklem büyüklükleri tablosundan (Büyüköztürk, Kılıç Çakmak, Akgün, Karadeniz ve Demirel, 2008) hareketle örneklem büyüklüğü belirlenmiştir. Ancak her okulda görev yapan sınıf öğretmenlerinin bir listesi oluşturulamadığı için ulaşılabilir evren içindeki ilkokullar listelenmiş ve her ilkokul bir küme kabul edilmiştir. Küme örnekleme yoluyla fiziki alan daraltılmış böylece hem etkililik hem de ekonomiklik (Balc1, 1997; Karasar, 2016) sağlanmıştır. Oluşturulan okul listesinden yansızlık kuralına göre belirlenen 37 ilkokul örneklem içine alınmıştır. Bu okullarda görev yapan 415 sınıf öğretmenine veri toplama araçları verilmiş, 380'i geri alınmış ve bunlardan 325'i geçerli görülmüştür. On maddeden fazla maddenin boş bırakıldığı anketler geçersiz sayılmıştır. Ölçümler geçerli görülen anketler üzerinden yapılmıştır. Bu şekilde en uygun (optimum) örneklem büyüklüğü olarak kabul edilen 341 öğretmenin \%95'ine ulaşılmıştır.

Araştırmanın örneklemini oluşturan öğretmenlerin 259'u (\%79.7) kadın, 66’s1 $(\% 20,3)$ erkektir. Öğretmenlerin 111'i (\%34.2) 0-10 yıl, 114'ü (\%35.1) 11-20 yıl ve 100 'ü de (\%30.8) 21 y1l ve üzeri k1deme sahiptir. Öğretmenlerin 270’i (\%83.1) devlet okulunda, 55'i (\%16.9) özel okulda görev yapmaktadır. Okuttukları sınıf düzeyi değişkenine göre türdeş (homojen) dağılım söz konusudur. Buna göre öğretmenlerin \%24.3'ü birinci sınıfları, \%28.6'sı ikinci sınıfları, \%20.9'u üçüncü sınıfları, \%26.2'si de dördüncü sınıfları okutmaktadır. Eğitim durumları yönünden ise öğretmenlerin \%88.3'ü lisans, \%11.7'si lisansüstü mezunudur.

\section{Veri Toplama Aracı ve Verilerin Toplanması}

İlkokul öğretmenlerinin öğrenciler arası rekabete ilişkin görüşleri, araştırmacılar tarafından geliştirilmiş ölçek formu ile elde edilmiştir. Ölçek formu iki bölümden oluşmaktadır. Birinci bölümde öğretmenlerin "Kişisel Bilgiler”ine yönelik sorular; ikinci bölümde de öğrenciler arası rekabetin olumlu-olumsuz etkilerine yönelik maddeler yer almıştır. 
Formun ikinci bölümü için yurtiçi ve yurtdışı kaynakların oluşturduğu geniş bir alanyazın taraması yapılmış, bu tarama sonucunda öğrenciler arası rekabete ilişkin olumlu ve olumsuz görüşleri temsil eden madde havuzu oluşturulmuştur. Her bir madde 5'li Likert tipi ölçeğe göre değerlendirilmiştir. Yanıt seçenekleri, "Tamamen katılıyorum" (4.50-5.00 puan aralığı), "Katılıyorum" (3.50-4.49 puan aralığı), "Orta düzeyde katılıyorum" (2.50-3.49 puan aralığı), "Katılmıyorum" (1.50-2.49 puan aralığı) ve "Hiç katılmıyorum" (1.00-1.49 puan aralığı) şeklinde derecelendirilmiştir. $\mathrm{Bu}$ şekilde oluşturulan veri toplama aracı, araştırmanın amaçlarına uygunluğu açısından "uzman ölçek formu" başlığı altında uzmanların görüşlerine sunulmuştur. Dokuz uzmanın incelemesi sonucunda bazı maddeler ölçekten çıkarılıp bazı maddeler ölçeğe eklenmiş ve bazı maddeler yeniden düzenlenerek ön deneme için hazırlanmıştır.

Araştırmanın ön deneme aşamasında Yenimahalle'de bulunan ilkokullarda 175 sınıf öğretmenine ölçek formları dağıtılmıştır. Dağıtılan ölçek formlarının 139'u geri alınmıştır. Bu ölçeklerin dokuzu, 10 maddeden fazla madde boş bırakıldığı için geçersiz sayılmıştır. Böylece 130 ölçek ile geçerlik-güvenirlik çalışmaları yapılmıştır.

Uzman görüşleri alınıp düzenlenen ölçek formlarının uygulanabilmesi için öncelikle Milli Eğitim Bakanlı̆̆ından gerekli izinler alınmıştır. Bu formlar okullar tek tek ziyaret edilerek uygulanmıştır. Ölçek formlarının nasıl doldurulacağına yönelik bir açıklama araca eklenmiştir. Bu konuda özellikle kişisel bilgilerin ve görüşlerin gizliliğinin nasıl sağlanacağı ve istendiği takdirde araştırmaya katılmaktan çekilebileceklerine yönelik bilimsel etik ilkeler doğrultusunda açıklamalar yapılmıştır.

\section{Geçerlik-Güvenirlik Çalışmaları}

Uzman değerlendirmesiyle düzenlenen "Öğrenciler Arası Rekabetin Etkilerine İlişkin Öğretmen Görüşleri” başlıklı ölçeğin geçerlik ve güvenirliği örneklem dışında yer alan 130 öğretmenden toplanan veriler üzerinden yapılmıştır. Analize başlamadan önce veriler üzende "kayıp veri ataması" yapılmış, kodlanan düz ve ters maddeler belirlenmiş, rekabeti olumsuzlayan 20 madde tersine puanlamıştır. Ölçeğin yapı geçerliğinin belirlenmesi için faktör analizi yapılmıştır. Faktör analizinin uygulanabilirliğini değerlendirmek için öncelikle Kaiser-Meyer-Olkin (KMO) testi Barlett Sphericity uygulanmıştır. Yapılan analizde KMO değeri 0.864 olarak belirlenmiştir. Faktör analizi öncesi maddelerin madde toplam korelasyonu hesaplanmıştır. Ayrıca madde yük değerleri de incelenmiştir. Faktör analizi sonucunda üç madde hiçbir boyuta dahil olmamıştır. Bu nedenle bu maddeler ölçekten çıkarılmıştır. Kalan 50 madde ile faktör analizine devam edilmiştir. Faktör analizi sırasında Varimax eksen döndürmesi (rotasyon) uygulanmıştır. Varimax eksen döndürmesi sonucunda ölçeğin dört alt boyutunun olduğu (Rekabetin Dezavantajları, Rekabetin Avantajları, Rekabetin Ruhsal Etkileri ve Rekabetin Eğitime Etkileri) ve varyansın \%57'sini açıladığı belirlenmiştir. Faktör analizi sonucunda Cronbach'ın Alfa katsayıları en küçük 0.706, en yüksek 0.969 arasında değişen dört boyutlu ölçeğin toplam güvenirlik katsayısı da (Cronbach Alfa) 0.957 olarak hesaplanmıştır. Belirlenen boyutlar altında yer alan maddelere ilişkin örnekler aşağıdaki gibidir: 
Rekabetin Dezavantajları Boyutu: Rekabet öğrenciler arasındaki paylaşma duygusunu yok etmektedir; rekabetçi eğitim uygulamaları öğrenciler arasında kutuplaşmaya neden olmaktadır; rekabete dayalı eğitim uygulamaları öğrencilerin birbirlerine karşı kalıp yargılar (güçlü, zayıf, tembel, aptal vb.) oluşturmalarına neden olmaktadır.

Rekabetin Avantajları Boyutu: Rekabetçi sınıf ortamlarında öğrenciler daha başarılı olmaktadırlar; rekabet öğrenme sürecini daha eğlenceli hale getirmektedir; Rekabete dayalı öğrenme, yararlı bir öğretim yaklaşımıdır.

Rekabetin Ruhsal Etkileri Boyutu: Rekabetçi sınıf ortamı, yavaş tempolu öğrencilerin benlik saygısını olumsuz etkilemektedir; rekabetçi öğrenme ortamında öğrenciler arasında kıskançlık duygusu ortaya çıkmaktadır; rekabet öğrencilerin stres yaşamasına neden olmaktadır.

Rekabetin Eğitime Etkileri Boyutu: Veli baskısı nedeniyle öğrencilerimi rekabet süreçlerine dahil ediyorum; okul yönetiminden (idaresinden) gelen baskı nedeniyle öğrencilerimi rekabet süreçlerine dahil ediyorum.

\section{Verilerin Analizi}

Araştırma, doğrudan çözümleme yöntemiyle analiz edilmiştir. Karasar’a göre (2016) doğrudan çözümleme, yalnızca gözlenen veya kaydedilen verilerin analiz edilmesidir. Bulunan değerler doğrudan çalışma grubunu temsil eder. Bu çalışmada yüzde (\%), frekans (N), aritmetik ortalama, standart sapma ve SPSS aracılığılla ileri istatistiksel analizler yapılmıştır. Ölçeğin alt boyutları için yapılan normallik testi Tablo 1'de yer almaktadır.

Tablo1

Öğretmenlerin Öğrenciler Arası Rekabetin Alt Boyutlarına İlişkin Puanlarının Normal Dağılıma Uygunluğuna İlişkin Analiz Sonuçları

\begin{tabular}{llcc}
\hline Alt Boyutlar & Çarpıklık- Basıklık Değeri & İstatistik & Standart Hata \\
\hline \multirow{2}{*}{ Rekabeti Dezavantajları } & Çarpıklık & .134 & .135 \\
& Basıklık & -.442 & .270 \\
\hline \multirow{2}{*}{ Rekabetin Avantajları } & Çarpıklık & .122 & .135 \\
& Basıklık & -.365 & .270 \\
\hline \multirow{2}{*}{ Rekabetin Ruhsal } & Çarpıklık & -.286 & .135 \\
Etkileri & Basıklık & .372 & .270 \\
\hline Rekabetin Eğitime & Çarpıklık & .141 & .135 \\
Etkileri & Basıklık & .114 & .270 \\
\hline
\end{tabular}

Tablo 1'de her dört boyutun sınır değerler arasında kaldığı ve normallik eğrisi gösterdiği görülmektedir. Bu aşamada öncelikle çarpıklık ve basıklık katsayısının +1 ve -1 arasında değişip değişmediği incelenmiştir. Analizlerde temel olan, puanların normalden aşırı sapma göstermemesidir. Çarpıklık katsayısı +1, -1 sınırları arasında ise puanların normal dağılımdan önemli bir şekilde sapmadığ yorumlanabilir (Büyüköztürk, 2017). 
Bu araştırmanın bağımlı değişkeni öğretmen görüşleri, bağımsız değişkenleri ise öğretmenlerin cinsiyetleri, kıdemleri, görev yaptıkları okul türü, eğitim durumları ve okuttukları sınıf düzeyleridir. Karşılaştırmaya alınan iki grup ortalaması aynı değişkene ait olduğundan öğretmenlerin görüşlerinin cinsiyet, okul türü ve eğitim durumlarına göre değişip değişmediğini belirlemek için "bağımsız örneklemler t testi”; ikiden fazla bağımsız grubun ortalamaları karşılaştırıldığından kıdem ve sınıf düzeyi değişkenleri için de "tek yönlü ANOVA” kullanılmıştır (Büyüköztürk, 2017). Tüm karşılaştırmalar için istatistiki önem seviyesi (p) .05 düzeyinde tutulmuştur.

\section{Bulgular}

$\mathrm{Bu}$ bölümde "İlkokul öğretmenlerinin rekabete ilişkin görüşleri nasıldır?" şeklinde belirtilen birinci alt probleme ilişkin görüşlerin yüzde, sıklık ve betimsel istatistik değerlerine ilişkin bulgular ve yorumlar yer almaktadır.

\section{Araştırmanın Birinci Alt Problemine İlişkin Bulgular}

Sınıf öğretmenlerinin öğrenciler arası rekabete ilişkin görüşleri 50 yarg1 üzerinden değerlendirilmiştir. Öğretmenler "Rekabet öğrencilerde kaygıya neden olmaktadır" ( $\overline{\mathrm{X}}=3.58)$, "Bazl ögrenciler rekabetin yarattı̆̆ baskı nedeniyle gerçek performanslarını (akademik, fiziksel, sosyal açıdan) gösterememektedirler" $(\overline{\mathrm{X}}=3.59)$, "Rekabetçi sınıf ortamı, yavaş tempolu öğrencilerin benlik saygısını olumsuz etkilemektedir" ( $\overline{\mathrm{X}}=3.62)$, "Rekabet öğrencilerin stres yaşamasina neden olmaktadır" ( $\overline{\mathrm{X}}=3.63)$ "Rekabet bazı öğrencilerin daha popüler olmasını sağlamaktadır" ( $\overline{\mathrm{X}}=3.65)$ ve "Rekabetçi ögrenme ortamında ögrenciler arasında kıskançlık duygusu ortaya çıkmaktadır" ( $\overline{\mathrm{X}}=3.77)$ yargılarına ortanın üzerinde katılım göstermiştir. Bir başka anlatımla öğretmenlerin bu yargılara katılmama düzeyleri \%15'in altındadır. Öte yandan öğretmenlerin \% 60'1 "Okul idaresinden gelen baskı nedeniyle ögrencilerimi rekabet süreçlerine dahil ediyorum" $(\overline{\mathrm{X}}=2.42)$ ve "Rekabetçi ĕgitim uygulamaları ögrencilerin cinsiyet ayrımı yapmalarına neden olmaktadır" ( $\overline{\mathrm{X}}=2.44)$ yargılarına katılmamaktadır. Öğretmenler burada ele alınan yargılar dışındaki 42 yargıya da orta düzeyde (2.50-3.49 puan aralığı) katılmaktadır.

\section{İkinci Alt Probleme İlişkin Bulgular}

Sınıf öğretmenlerinin öğrenciler arası rekabetin alt boyutlarına ilişkin puanlarının cinsiyete göre " $t$ ” testi sonuçları Tablo 2'de yer almaktadır.

Tablo 2

Öğretmenlerin Öğrenciler Arası Rekabetin Alt Boyutlarına İlişkin Puanlarının Cinsiyetlerine Göre " $t$ ” Testi Sonuçlart

\begin{tabular}{lccccccc}
\hline Rekabetin Alt Boyutları & Cinsiyet & $\mathbf{N}$ & $\overline{\mathbf{X}}$ & SS & t & sd & p \\
\multirow{2}{*}{ Rekabetin Dezavantajları } & Erkek & 66 & 3.03 & 0.86 & 0.81 & 323 & 0.41 \\
& Kadın & 259 & 3.13 & & & & \\
\hline \multirow{2}{*}{ Rekabetin Avantajları } & Erkek & 66 & 2.81 & 0.77 & -1.71 & 323 & 0.08 \\
& Kadın & 259 & 2.99 & 0.75 & & & \\
\hline
\end{tabular}


Tablo 2 (devam)

\begin{tabular}{lccccccc}
\hline Rekabetin Alt Boyutları & Cinsiyet & $\mathbf{N}$ & $\overline{\mathbf{X}}$ & $\mathbf{S S}$ & $\mathbf{t}$ & sd & $\mathbf{p}$ \\
\hline Rekabetin Duygusal/Ruhsal & Erkek & 66 & 3.33 & 0.75 & -1.87 & 323 & 0.06 \\
Etkileri & Kadın & 259 & 3.50 & 0.65 & & & \\
\hline \multirow{2}{*}{ Rekabetin Eğitime Etkileri } & Erkek & 66 & 2.97 & 0.74 & 1.52 & 323 & 0.12 \\
& Kadın & 259 & 2.82 & 0.73 & & & \\
\hline \multirow{2}{*}{ Genel Ortalama } & Erkek & 66 & 2.99 & 0.60 & -1.45 & 323 & 0.14 \\
& Kadın & 259 & 3.10 & 0.53 & & & \\
\hline
\end{tabular}

Tablo 2'deki genel ortalama ve tüm alt boyutlar incelendiğinde öğretmenlerin görüşleri cinsiyete göre dört boyutta da istatistiksel olarak anlamlı bir farklılık göstermemektedir. Ancak boyutların altında yer alan bazı yargılarda öğretmenlerin görüşleri cinsiyetlerine göre farklılaşmaktadır. Örneğin "Rekabetçi eğitim uygulamaları ögrenciler arasında kutuplaşmaya neden olmaktadır” (Kadın $\overline{\mathrm{X}}=3.32$; Erkek $\overline{\mathrm{X}}=2.97)$, "Rekabetçi sınıf ortamlarında ögrenciler daha başarll olmaktadırlar" (Kadın $\overline{\mathrm{X}}=3.05$; Erkek $\overline{\mathrm{X}}=2.73)$; "Rekabete dayalı eğitim uygulamaları, ögrencileri geleceğin rekabetçi dünyasına hazırlamaktadır" (Kadın $\overline{\mathrm{X}}=3.00 ; \quad$ Erkek $\overline{\mathrm{X}}=2.71)$; "Rekabet baskıs ögrencileri daha çok çalışmaya yöneltmektedir" (Kadın $\overline{\mathrm{X}}=3.04$; Erkek $\overline{\mathrm{X}}=2,76)$; "Rekabet ögrencinin kapasitesini zorlaması için gereklidir" (Kadın $\overline{\mathrm{X}}=3.03$; Erkek $\overline{\mathrm{X}}=2.71$ ); "Rekabet ögrencilerde kayglya neden olmaktadır" (Kadın $\overline{\mathrm{X}}=3.64 ;$ Erkek $\overline{\mathrm{X}}=3.36$ ); "Rekabet ögrencilerin stres yaşamasına neden olmaktadır" (Kadın $\overline{\mathrm{X}}=3.71$; Erkek $\overline{\mathrm{X}}=3.33$ ) yargılarına kadın ve erkek öğretmenlerin katılma düzeyi istatistiksel olarak .95 güven aralığı içinde anlamlı farklılık göstermiştir. Bir başka ifade ile kadın öğretmenler bu yargılara erkek öğretmenlerden daha yüksek düzeyde katılmıştır. Ayrıca "Rekabet ögrenciler arasında eşitlik ve adalet duygusunu yok eden bir yaklaşımdır" yargısının cinsiyete göre aritmetik ortalamaları ise eşittir (Kadın $\bar{X}=3.08$; Erkek $\bar{X}=3.08)$. Hem kadın hem de erkek öğretmenler bu yargıya orta düzeyde katılım göstermişlerdir. İstatistiksel olarak anlamlı farklılık olmamakla birlikte aritmetik ortalamalar açısından bakıldığında kadın öğretmenler rekabetin dezavantajları ve duygusal/ruhsal etkilerine, erkek öğretmenler de rekabetin eğitim-öğretim sürecine yönelik etkilerine daha çok katılmaktadır.

Sınıf öğretmenlerinin öğrenciler arası rekabetin alt boyutlarına ilişkin puanlarının görev yaptıkları okul türüne göre "t'" testi sonuçları Tablo 3 'te yer almaktadır.

Tablo 3

Öğretmenlerin Öğrenciler Arası Rekabetin Alt Boyutlarına İlişkin Puanlarının Görev Yaptıklarl Okul Türüne Göre " $t$ ” Testi Sonuçlart

\begin{tabular}{llcccccc}
\hline Rekabetin Alt Boyutları & Okul Türü & $\mathbf{N}$ & $\overline{\mathbf{X}}$ & SS & T & sd & p \\
\hline Rekabetin & Devlet Okulu & 270 & 3.04 & 0.86 & -3.22 & 323 & $0.00^{* *}$ \\
Dezavantajları & Özel Okul & 55 & 3.44 & 0.77 & & & \\
\hline \multirow{2}{*}{ Rekabetin Avantajları } & Devlet Okulu & 270 & 2.94 & 0.76 & -0.49 & 23 & 0.62 \\
& Özel Okul & 55 & 3.00 & 0.75 & & & \\
\hline
\end{tabular}


Tablo 3 (devam)

\begin{tabular}{lllccccc}
\hline Rekabetin Alt Boyutları & Okul Türü & $\mathbf{N}$ & $\overline{\mathbf{X}}$ & $\mathbf{S S}$ & $\mathbf{T}$ & sd & $\mathbf{p}$ \\
\hline Rekabetin Duygusal / & Devlet Okulu & 270 & 3.44 & 0.66 & -1.75 & 23 & 0.08 \\
Ruhsal Etkileri & Özel Okul & 55 & 3.61 & 0.73 & & & \\
\hline \multirow{2}{*}{ Rekabetin Eğitime Etkileri } & Devlet Okulu & 270 & 2.89 & 0.71 & 1.99 & 23 & $0.04^{* *}$ \\
& Özel Okul & 55 & 2.67 & 0.83 & & & \\
\hline \multirow{2}{*}{ Genel Ortalama } & Devlet Okulu & 270 & 3.05 & 0.56 & -2.37 & 23 & $0.01^{* *}$ \\
& Özel Okul & 55 & 3.24 & 0.44 & & & \\
\hline
\end{tabular}

Tablo 3'te "Genel Ortalama" incelendiğinde öğretmenlerin öğrenciler arası rekabete ilişkin görüşlerinin görev yaptıkları okul türlerine göre istatistiksel olarak .95 güven aralığı içinde anlamlı bir şekilde farklılaştığ görülmektedir (Devlet Okulu $\overline{\mathrm{X}}=3.05$, Özel Okul $\overline{\mathrm{X}}=3.24, \mathrm{p}<.05$ ). "Rekabetin Dezavantajları" boyutunda okul türü değişkeni yönünden özel okul ve devlet okulunda çalışan öğretmenlerin görüşlerinde anlamlı farklılık gözlenmiştir (Devlet Okulu $\overline{\mathrm{X}}=3.04$, Özel Okul $\overline{\mathrm{X}}=3.44, \mathrm{p}<$.05). Özel okulda çalışan öğretmenler devlet okulunda çalışan öğretmenlere göre Rekabetin Dezavantajları boyutundaki 21 yargının 10'una ortanın üzerinde katılmaktadır. Bir başka deyişle ile özel okulda görev yapan sınıf öğretmenleri rekabetin bilişsel, sosyal, psikolojik açılardan öğrencilerde yol açtığı olumsuz etkilerine (paylaşma duygusunu yok etme, kalıp yargıların ortaya çıkması, eşitlik ve adaletin olmaması, sosyal dışlanma, arkadaşlık ilişkilerine zarar verme, şiddet içeren davranışlar, kaybetmenin utanç ve değersizlik hissine yol açması, yalan ve hileye başvurulması, akran zorbalığına yol açması, birbirlerine karşı güven duygusunu ve dayanışmayı yok etmesi ve öğrenmeyi olumsuz etkileme gibi) yönelik yargılara devlet okulunda çalışan öğretmenlere göre daha çok katılmaktadır.

Rekabetin Eğitime Etkileri boyutunun genel ortalaması ise görev yapılan okul türüne göre anlamlı farklılık göstermiştir (Devlet Okulu $\overline{\mathrm{X}}=2.89$, Özel Okul $\overline{\mathrm{X}}=2.67$, $\mathrm{p}<0.05)$. Bu boyutta ise "Rekabete dayall olmayan eğitim uygulamalarinda ögrencileri adil bir şekilde değerlendirmek mümkün olmamaktadır" (Devlet Okulu $\overline{\mathrm{X}}=3.20$, Özel Okul $\overline{\mathrm{X}}=2.76$ ); "Rekabetçi olmayan ögrenme ortamında bireysel çabalar boşa gitmektedir" (Devlet Okulu $\overline{\mathrm{X}}=3.16$, Özel Okul $\overline{\mathrm{X}}=2.51$ ) ve "Rekabete dayall olmayan ĕgitim uygulamalarl ĕgitim-öğretimin niteliğini düşürmektedir" (Devlet Okulu $\bar{X}=3.24$, Özel Okul $\bar{X}=2.87$ ) yargılarına devlet okulunda görev yapan öğretmenler özel okulda görev yapan öğretmenlere göre daha çok katılım göstermektedir.

Sınıf öğretmenlerinin öğrenciler arası rekabete ilişkin görüşlerinin eğitim durumlarına göre farklılaşıp farklılaşmadığına yönelik “ $t$ ” testi sonuçları Tablo 4'te verilmiştir. 
Tablo 4

Öğretmenlerin Öğrenciler Arası Rekabetin Alt Boyutlarına İlişkin Puanlarının Ĕ̆gitim Durumlarına Göre " $t$ ” Testi Sonuçlart

\begin{tabular}{llcccccc}
\hline Rekabetin Alt Boyutları & Eğitim Durumu & $\mathbf{N}$ & $\overline{\mathbf{X}}$ & $\mathbf{S S}$ & $\mathbf{T}$ & $\mathbf{S d}$ & $\mathbf{p}$ \\
\hline \multirow{2}{*}{ Rekabetin Dezavantajları } & Lisans & 287 & 3.13 & 0.84 & 1.05 & 23 & 0.29 \\
& Lisansüstü & 38 & 2.97 & 1.00 & & & \\
\hline \multirow{2}{*}{ Rekabetin Avantajları } & Lisans & 287 & 2.98 & 0.75 & 1.39 & 23 & 0.16 \\
& Lisansüstü & 38 & 2.73 & 0.82 & & & \\
\hline Rekabetin Duygusal / & Lisans & 287 & 3.48 & 0.64 & 0.94 & 23 & 0.34 \\
Ruhsal Etkileri & Lisansüstü & 38 & 3.37 & 0.90 & & & \\
\multirow{2}{*}{ Rekabetin Eğitime Etkileri } & Lisans & 287 & 2.85 & 0.72 & -0.15 & 23 & 0.87 \\
& Lisansüstü & 38 & 2.87 & 0.84 & & & \\
\hline \multirow{2}{*}{ Genel Ortalama } & Lisans & 287 & 3.10 & 0.54 & 1.49 & 23 & 0.13 \\
& Lisansüstü & 38 & 2.95 & 0.62 & & & \\
\hline
\end{tabular}

Tablo 4'te görüldüğü gibi genel ortalamaya göre öğretmenlerin rekabetin dezavantajlarına ilişkin görüşleri eğitim durumlarına göre farklılaşmamaktadır (Lisans $\overline{\mathrm{X}}=3.10$ Lisansüstü $\overline{\mathrm{X}}=2.95 \mathrm{p}>.05$ ). Ancak boyutların altında yer alan "Rekabet akran zorbalığına neden olmaktadır" (Lisans $\overline{\mathrm{X}}=3.18$;Lisansüstü $\overline{\mathrm{X}}=2.58$ ), "Sınıfta gruplararası rekabet, grup üyelerinin işbirliği yapmalarını să̆lamaktadır" (Lisans $\overline{\mathrm{X}}=3.05$; Lisansüstü $\overline{\mathrm{X}}=2.66$ ) ve "Rekabet ögrencilerde kayglya neden olmaktadır" (Lisans $\overline{\mathrm{X}}=3.63$; Lisansüstü $\overline{\mathrm{X}}=3.18$ ) yargılarına ilişkin öğretmen görüşleri eğitim durumu değişkenine göre .95 güven aralığında istatistiksel olarak anlamlı bir şekilde farklılaşmaktadır.

Lisans mezunu olan öğretmenlerin görüşlerinin aritmetik ortalamaları lisansüstü mezuniyeti olan öğretmenlerin görüşlerinin aritmetik ortalamalarından daha yüksektir. Sınıf öğretmenlerinin öğrenciler arası rekabete ilişkin görüşlerinin kıdemlerine (hizmet süresi) göre farklılaşıp farklılaşmadığının ANOVA testi sonuçları Tablo 5'te incelenmiştir.

Tablo 5

Öğretmenlerin Öğrenciler Arası Rekabetin Alt Boyutlarına İlişkin Puanlarının Kıdemlerine Göre "ANOVA" Testi Sonuçları

\begin{tabular}{|c|c|c|c|c|c|c|c|c|}
\hline Rekabetin Alt Boyutları & Kıdem & $\mathbf{N}$ & $\overline{\mathbf{X}}$ & SS & sd & $\mathbf{F}$ & $\mathbf{p}$ & Fark \\
\hline \multirow[t]{4}{*}{ Rekabetin Dezavantajları } & $0-10$ y1l & 111 & 3.25 & 0.93 & 324 & 2.48 & .08 & \\
\hline & $11-20 \mathrm{y} 11$ & 114 & 3.02 & 0.80 & & & & \\
\hline & $21-46$ y1l & 100 & 3.04 & 0.83 & & & & \\
\hline & Toplam & 325 & 3.11 & 0.86 & & & & \\
\hline \multirow[t]{4}{*}{ Rekabetin Avantajları } & $0-10$ y1l & 111 & 2.91 & 0.79 & 324 & 0.26 & .76 & \\
\hline & $11-20$ y1l & 114 & 2.96 & 0.75 & & & & \\
\hline & $21-46$ y1l & 100 & 2.99 & 0.73 & & & & \\
\hline & Toplam & 325 & 2.95 & 0.76 & & & & \\
\hline
\end{tabular}


Tablo 5 (devam)

\begin{tabular}{|c|c|c|c|c|c|c|c|c|}
\hline Rekabetin Alt Boyutları & Kıdem & $\mathbf{N}$ & $\overline{\mathbf{X}}$ & SS & Sd & $\mathbf{F}$ & p & Fark \\
\hline \multirow{4}{*}{$\begin{array}{l}\text { Rekabetin Duygusal/Ruhsal } \\
\text { Etkileri }\end{array}$} & $0-10$ y1l & 111 & 3.55 & 0.70 & 324 & 1.29 & .27 & \\
\hline & $11-20 \mathrm{y} 1 \mathrm{l}$ & 114 & 3.43 & 0.58 & & & & \\
\hline & $21-46$ y1l & 100 & 3.41 & 0.74 & & & & \\
\hline & Toplam & 325 & 3.47 & 0.67 & & & & \\
\hline \multirow{4}{*}{ Rekabetin Eğitime Etkileri } & $0-10$ y1l & 111 & 2.69 & 0.69 & 324 & 9.19 & $.00 * *$ & $0-10$ \\
\hline & $11-20$ y1l & 114 & 2.79 & 0.70 & & & & y1l ile \\
\hline & $21-46$ y1l & 100 & 3.10 & 0.75 & & & & $21-46$ \\
\hline & Toplam & 325 & 2.85 & 0.73 & & & & $\begin{array}{c}\text { y1l } \\
\text { aras1 }\end{array}$ \\
\hline \multirow{4}{*}{ Genel Ortalama } & $0-10$ y1l & 111 & 3.12 & 0.53 & 324 & 0.69 & .50 & \\
\hline & $11-20 \mathrm{y} 1 \mathrm{l}$ & 114 & 3.04 & 0.48 & & & & \\
\hline & $21-46$ y1l & 100 & 3.08 & 0.63 & & & & \\
\hline & Toplam & 325 & 3.08 & 0.55 & & & & \\
\hline
\end{tabular}

Öğretmenlerin kıdemlerine göre, öğrenciler arası rekabetin eğitime etkileri boyutu haricindeki puanları farklılaşmamaktadır. Kıdem değişkenine göre sadece "Rekabetin Eğitime Etkileri" boyutunda istatistiksel olarak anlamlı farklılık görülmektedir $\quad(0-10$ y1l $\overline{\mathrm{X}}=2.69 ; 11-20$ y1l $\overline{\mathrm{X}}=2.79 ; 21-46$ y1l $\overline{\mathrm{X}}=3.10 ; \mathrm{p}<.05)$. Grupların varyansları homojen olduğu için farklılığın kaynağını belirlemede Post Hoc testlerinden olan Tukey testi yapılmıştır. Buna göre göre anlamlı farklılığın 1-10 yıl arası kıdeme sahip olan öğretmenlerle 21-46 yıl arası kıdeme sahip olan öğretmenler arasında olduğu saptanmıştır. 1-10 yıl arasında kıdeme sahip olan öğretmenlerin rekabetin öğrencinin eğitimine yönelik olumsuz etkilerine katılma düzeyleri 21-46 yıl kıdeme sahip öğretmenlerden daha yüksektir.

İlkokul öğretmenlerinin öğrenciler arası rekabete ilişkin görüşlerinin okuttukları sınıf düzeylerine göre farklılaşıp farklılaşmadığına ilişkin ANOVA testi Tablo 6'da yer almaktadır.

Tablo 6

Ögretmenlerin Öğrenciler Arası Rekabetin Alt Boyutlarına İlişkin Puanlarının Okuttukları Sinıf Düzeylerine Göre "ANOVA" Testi Sonuçları

\begin{tabular}{lccccccc}
\hline Rekabetin Alt Boyutları & Sinıf & N & $\overline{\mathbf{X}}$ & SS & Sd & F & p \\
\hline \multirow{4}{*}{ Rekabetin Dezavantajları } & 1 & 79 & 3.09 & 0.92 & 324 & 0.10 & 0.95 \\
& 2 & 93 & 3.15 & 0.88 & & & \\
& 3 & 68 & 3.10 & 0.83 & & & \\
& 4 & 85 & 3.08 & 0.81 & & & \\
Rekabetin Avantajlar1 & Toplam & 325 & 3.11 & 0.86 & & & \\
& 1 & 79 & 2.90 & 0.83 & 324 & 0.89 & 0.44 \\
& 2 & 93 & 2.90 & 0.71 & & & \\
& 3 & 68 & 3.07 & 0.75 & & & \\
& 4 & 85 & 2.97 & 0.73 & & & \\
\hline
\end{tabular}


Tablo 6 (devam)

\begin{tabular}{lccccccc}
\hline Rekabetin Alt Boyutları & Sinıf & $\mathbf{N}$ & $\overline{\mathbf{X}}$ & SS & Sd & $\mathbf{F}$ & $\mathbf{p}$ \\
\hline \multirow{3}{*}{ Rekabetin Duygusal / } & 1 & 79 & 3.45 & 0.75 & 324 & 0.09 & 0.96 \\
Ruhsal Etkileri & 2 & 93 & 3.47 & 0.67 & & & \\
& 3 & 68 & 3.50 & 0.64 & & & \\
& 4 & 85 & 3.45 & 0.63 & & & \\
& Toplam & 325 & 3.47 & 0.67 & & & \\
Rekabetin Eğitime Etkileri & 1 & 79 & 2.80 & 0.83 & 324 & 0.24 & 0.86 \\
& 2 & 93 & 2.84 & 0.60 & & & \\
& 3 & 68 & 2.88 & 0.70 & & & \\
& 4 & 85 & 2.89 & 0.79 & & & \\
Genel Ortalama & Toplam & 325 & 2.85 & 0.73 & & & \\
& 1 & 79 & 3.05 & 0.57 & 324 & 0.24 & 0.86 \\
& 2 & 93 & 3.08 & 0.52 & & & \\
& 3 & 68 & 3.13 & 0.55 & & & \\
& 4 & 85 & 3.08 & 0.56 & & & \\
\hline
\end{tabular}

Tablo 6'da görüldüğü gibi öğrenciler arası rekabete ilişkin boyutlar arasında sınıf öğretmenlerinin okuttukları sınıf düzeylerine ilişkin anlamlı farklılık yoktur. Ayrıca aritmetik ortalamaları birbirine çok yakındır (1. sınıf $\bar{X}=3.05,2$. sınıf $\bar{X}=$ 3.08, 3. sınıf $\bar{X}=3.13,4$. sınıf $\bar{X}=3.08$ p> .05). Buna göre öğrenciler arası rekabete ilişkin görüşlerde, öğretmenlerin okuttukları sınıf düzeyi belirleyici değildir.

\section{Sonuç, Tartışma ve Öneriler}

$\mathrm{Bu}$ araştırmada sınıf öğretmenlerinin eğitim-öğretim ortam ve uygulamalarında öğrenciler arası rekabetin genel ve öğrencilere etkilerine yönelik görüşleri belirlenmiştir. Araştırmaya katılan sınıf öğretmenleri, öğrenciler arası rekabetin hem olumlu hem de olumsuz etkilerine ilişkin 50 yargının 42'sine orta düzeyde katılım göstermişlerdir. İlkokul öğretmenlerinin öğrenciler arası rekabete ilişkin olumlu ve olumsuz yargıların \%80'ine “orta düzeyde" katılım göstermeleri, öğretmenlerin rekabetin olumlu ve olumsuz yönleri konusunda bütünüyle taraf olmadıklarını göstermektedir. Ancak öğretmenlerin çoğu rekabetin öğrencilerde yaratacağı olumsuz psiko-sosyal etkilere de ortanın üzerinde katılım göstermiştir. Öğretmenlerin rekabetin öğrencilerde yarattığ1 "kıskançlık, olumsuz benlik algısı, stres, kayg1, rekabet baskısının yarattığı olumsuz sosyal ilişkiler" gibi yargılara "daha yüksek" oranda katılmış olmaları rekabetin olumsuz yönlerinin farkında olduklarının da bir göstergesidir. En yüksek ortalamalar incelendiğinde sınıf öğretmenlerinin, rekabetin öğrenciler üzerinde kıskançlık duygusunu, popüler olma isteğiyle beraber gelen ayrımcılığ1 ve üzerlerindeki baskı ve stresi artırdığ1 yönünde bir kanıya sahip oldukları söylenebilir. Zhao (2015) ile Malkoç ve Erginsoy'un (2012) çalışmalarında da benzer şekilde rekabetin kıskançlık duygusunu ortaya çıkardığı saptanmıştır. Bunun yanında rekabetin öğrencilerde kaygı ve stresi artırdığ 1 ile ilgili çalışmalar da vardır. Gilbert ve diğ., (2009), rekabetçi davranışların benlik saygısını olumsuz etkilediğini; bunun 
da depresyon, anksiyete ve kendine zarar verme ile ilintili olduğunu bulmuştur. Heinrich (2014), rekabetin bazı öğrencilerde not kaygısıyla benlik saygılarının zedeleneceğini, bu durumun stres, kaygı ve depresyona yol açacağını belirtmiştir. Hilk (2013) rekabet üzerine yaptığı kapsamlı meta-analiz çalışmasında, rekabetin şiddete ve akran zorbalığına yol açtığını belirten çalışmaları incelemiş ve rekabetin benlik saygısını, özgüveni, uyumluluk potansiyelini, olumlu sosyal ilişkileri zedeleyeceğini ortaya çıkarmışıır. $\mathrm{Bu}$ çalışmalar rekabetin stresi artırdığı yönündeki bulguyla örtüşmektedir. Bunun yanında Johnson ve Johnson çalışmalarının çoğunda rekabetçi öğrenme ortamlarında işbirlikçi öğrenme ortamına göre öğrencilerin daha düşük düzeyde akademik başarı gösterdiğini bulmuştur (Johnson ve diğ., 1981; Johnson ve Johnson, 1984; Johnson ve diğ., 1985); Skon ve diğ., (1981) de rekabetçi ve işbirlikçi eğitim ortamlarında bulunan öğrencilerin başarımları (performans) karşılaştırıldığında rekabetçi ortamda öğrencilerin daha düşük akıl yürütme becerisi geliştirdiklerini ve rekabetçi eğitim ile öğrencilerin akademik başarıları arasında negatif ilişki olduğunu saptamıştır. Johnson ve Johnson (1985), rekabetçi ortamda akranlar arasında sürtüşmelerin yaşandığını, yardımlaşmanın azaldığını gözlemlemiştir. Ladd ve Fiske de (2003), çalışmalarında rekabetin öğrenme kalitesi üzerinde negatif etkisi olduğu sonucuna ulaşmıştır.

Sınıf öğretmenlerinin öğrenciler arası rekabete ilişkin görüşleri "cinsiyet" değişkeni yönünden anlamlılık göstermemesine karşın ölçeğin alt boyutlarındaki bazı yargılara cinsiyete göre daha yüksek katılım gözlemlenmiştir. Kadın öğretmenler genel olarak erkek öğretmenlere göre rekabeti daha olumsuz görmektedir. Ancak kadın öğretmenler kendi içlerinde de çelişkili görüşlere sahiptirler. Şöyle ki kadın öğretmenler, rekabetin öğrenciler arasında kutuplaşmaya neden olması, öğrencilerde stres ve kaygıya yol açması gibi rekabeti olumsuzlayan yargıları erkek öğretmenlerden daha çok desteklerken; rekabetçi sınıf ortamlarında öğrencilerin daha başarılı olduğu, rekabetin öğrencilerin kapasitesini zorlamaları için gerekli olduğu, rekabetçi sınıf ortamının öğrencileri geleceğin rekabetçi dünyasına hazırladığı ve rekabet baskısının öğrencileri daha fazla çalışmaya yönelttiği gibi rekabeti olumlayan yargıları da erkek öğretmenlerden daha çok desteklemektedir. Hem kadın hem erkek öğretmenler rekabetin öğrenciler arasında eşitlik ve adalet duygusunu yok eden bir yaklaşım olduğu konusunda hemfikirdir. Nitekim Cantador ve Conde (2010) da rekabetin mutlaka bir kazanan bir kaybedeni olduğunu belirtmektedir. Öyleyse rekabete dayalı uygulamalarda eşitlikten söz etmek de gerçekçi olmayacaktır.

Okul türü (devlet-özel) değişkeni öğretmenlerin öğrenciler arası rekabete ilişkin görüşlerinde belirleyicidir. Genel olarak özel okulda görev yapan öğretmenler devlet okulunda görev yapan meslektaşlarına göre öğrenciler arasındaki rekabeti daha az desteklemektedir. Özel okulda çalışan öğretmenleri devlet okulunda çalışan öğretmenlere göre, özellikle rekabetin olumsuz etkileri boyutunda öğrencilerin "paylaşma, eşitlik ve adalet, sosyal dayanışma, güven, öğrenmenin niteliği, dayanışma, arkadaşlık ilişkileri" gibi değerler yönünden daha fazla olumsuz etkilendikleri düşüncesindedir. Özel okul öğretmenleri rekabetin "kaybetme-utanç, kaybetme-değersizlik, stres, akran zorbalığı, şiddet, arkadaşlarına karşı kalıp yargılar 
türetme, yalan söyleme, hile yapma" gibi olumsuz etkilere yol açacağına yönelik yargılara daha yüksek katılım göstermiştir. Bu sonuç, maddi kazancı ön planda tutarak pazar (piyasa) koşullarında çalışan özel okulların (Aksoy, Deniz ve Algan, 2017) kendi aralarındaki öğrenci çekme yarışıyla ve buna bağlı olarak da hem öğretmenler hem de öğrenciler üzerinde başarılı olmak için daha çok baskı yapılmasıyla ilişkili olabileceğini düşündürmektedir. Dolayısıyla özel okulların işleyiş açısından rekabetçi kurumlar olduğu belirtilebilir. Bu kurumlarda görev yapan öğretmenler devlet okullarındakine göre da az sayıda olan öğrencileriyle daha çok zaman geçiriyor ve rekabetin öğrenciler üzerindeki yıkıcı etkilerini daha çok gözlemliyor olabilirler. Öte yandan devlet okulunda görev yapan öğretmenler ise rekabete dayalı olmayan eğitim uygulamalarında öğrencileri adil bir şekilde değerlendirmenin olanaklı olmayacağı, eğitim-öğretimin niteliğinin düşeceği ve öğrencilerin bireysel çabalarının boşa gideceği görüşündedir. Sınavlar özellikle 1980'lerden itibaren Türk eğitim sisteminde bir norm biçimine gelmiş, öğrenci başarısını ölçmede en akılcı (rasyonel) ve eşitlikçi bir araçmış gibi görülmeye başlanmıştır (İnal, 2008). Araştırmaya katılan öğretmenler bu anlayış ve kanıksama içerisinde sınavsız adil bir değerlendirmenin olanaklı olmayacağı görüşünü taşıyor olabilirler.

Araştırmaya katılan öğretmenlerin öğrenciler arası rekabete ilişkin görüşleri "eğitim durumu” değişkeni yönünden genel olarak değişmemektedir. Sınıf öğretmenlerinin öğrenciler arasındaki rekabete ilişkin görüşleri, lisans mezunu öğretmenler ile lisansüstü mezunu öğretmenler arasında belirleyici değildir. Ancak lisans mezunu olan öğretmenler lisansüstü mezunlarına göre bir yandan rekabetin akran zorbalığına ve kaygıya neden olacağı, öte yandan gruplararası rekabetin, grup üyeleri arasında işbirliği yapmalarını sağlayacağı yargılarına daha çok katılmaktadır. Lisans mezunu öğretmenler rekabetin öğrencilerde yaratacağı olumsuz etkilere karşın gruplararası rekabetin olumlu katkı getireceği görüşünü taşıyor olabilirler. Nitekim alanyazında da takımlar arasında iyi oluşturulmuş bir rekabetin öğrencilerin öğrenme becerilerini geliştirdiği belirtilmektedir (Cantador ve Bellogin, 2012; Thousand ve diğ., 1994).

Araştırmaya katılan öğretmenlerin öğrenciler arası rekabete ilişkin görüşleri "kıdem (hizmet süresi)" değişkeni yönünden birkaç maddede anlamlılık göstermektedir. Genel itibariyle 10 yıla kadar kıdemi olan öğretmenler, 10 yılın üzerinde kıdeme sahip meslektaşlarına göre öğrenciler arası rekabetin olumsuz etkilerine daha çok katılmaktadır. 0-10 yıl arası kıdeme sahip olan öğretmenler rekabetin öğrenciler arasında eşitlik ve adaleti yok ettiği, rekabetin yavaş tempolu öğrencilerin benlik saygısını olumsuz etkilediği, rekabetçi ortamdaki kaybetme korkusunun düşük performansa yol açtığı, öğrencilerin birbirlerine karşı kalıp yargılar oluşturduğu gibi dezavantajların daha çok farkındadır. Bu durum genç kuşak öğretmenlerin kıdemli öğretmenlere göre 1980 sonrasında daha rekabetçi dönemde eğitim almış olmaları ve rekabetin etkilerini kendi yaşantılarında da hissetmiş olmaları ile açıklanabilir. Araştırmaya katılan öğretmenlerin öğrenciler arası rekabete ilişkin görüşleri okuttukları "sınıf düzeyi” değişkeni yönünden değişmemektedir. 
Araştırmada sınıf öğretmenlerinin görüşleri rekabete ilişkin bazı yargılarda cinsiyet, okul türü, eğitim durumu ve kıdem değiş̧kenleri açısından anlamlı farklılıklar göstermiştir. Bu farklılıkların kaynağının belirlenebilmesi için yapılacak yeni çalışmalar konuya ilişkin farklı açılımlar sağlayacaktır. Alanda yapılacak yeni çalışmaların sınıf içi gözlem ve görüşmelerle desteklenmesi eğitimin öznesi olarak öğrencilerin rekabete karşı davranış ve tutumlarının da ortaya konulmasını sağlayacaktır. İlkokulda sınıf içi rekabetin öğrenciler üzerinde yaratacağı kaygı ve stres ile ilgili çalışmalar araştırmacılara derinlemesine bir inceleme alanı oluşturabilir. Öğrenciler arası rekabetin işbirliği, saygı, paylaşma, dayanışma gibi değerlerin kazanımını ne yönde etkilediği üzerine yapılacak çalışmalar da eğitimin amaçları, içeriği, öğrenme-öğretme yöntemleri ile ölçme değerlendirme süreçlerinin gözden geçirilmesinde karar mekanizmalarına bilimsel veriler sunacaktır.

\section{Etik Kurul Kararı}

$\mathrm{Bu}$ araştırma, 01.01.2020 tarihinden önce yapıldığı için etik kurul kararı zorunluluğu taşımamaktadır.

\section{Kaynakça}

Akbayırlı, Y. B. (1998). Bir ölçek geliştirme çalışması: Rekabetçi tutum ölçeği (RTÖ); geliştirilmesi, güvenilirliği ve geçerliliği (Yayımlanmamış yüksek lisans tezi). https://tez.yok.gov.tr/UlusalTezMerkezi// sayfasından erişilmiştir (Tez No. 71862).

Aksoy, N., Deniz, E. E. ve Algan, B. (2017). Kamu okullarındaki piyasalaşma. N. S. Baykal, A. Ural ve Z. Alica (Ed.), Eleştirel eğitim seçkisi içinde (ss. 9-31). Ankara: Pegem.

Aksoy, H. H., Akgündüz, M. M., Demir, N., Tunacan, S., Türk, F. ve Uğur, N. (2017). Eğitimde merkezi sınavlara ilişkin eleştiriler. N. S. Baykal, A. Ural ve Z. Alica (Ed.), Eleştirel eğitim seçkisi içinde (ss. 32-55). Ankara: Pegem.

Bolat, Ö. (2009, 2 Ekim). Rekabet çocukları nasıl etkiliyor? Hürriyet. http://www.hurriyet.com.tr/rekabet-cocuklari-nasil-etkiliyor-12598043 sayfasından erişilmiştir.

Balcı, A. (1997). Sosyal bilimlerde araştırma: Yöntem, teknik ve ilkeler (2. bas.) Ankara: Pegem Akademi.

Büyüköztürk Ş., Kılıç Çakmak E., Akgün Ö. E., Karadeniz Ş. ve Demirel F. (2008). Bilimsel araştırma yöntemleri. (21. bas.) Ankara: Pegem Akademi.

Büyüköztürk, Ş. (2017). Sosyal bilimler için veri analizi el kitabı. Istatistik, araştırma deseni spss uygulamalarl ve yorum. (23. bas.). Ankara: Pegem Akademi.

Cantador, I., and Bellogin, A. (2012). Healty competititons in education trough cooperation

learning. 
https://pdfs.semanticscholar.org/db1c/61ac1795f6cb9c97b916246c3d47d 7c015be.pdf sayfasından erişilmiştir.

Cantador, I., and Conde, J. M. (2010). Effects of competition in education: A case study in an e-learning environment. Paper presented at the IADIS Multi Conference on Computer Science and Information Systems, Albert Ludwigs University, Freiburg.

Clifford, M. M. (1989). Competition: Can the assets exceed the liabilities? New Designs in Youth Development, 9(1/3), 25-30.

Cumhurbaşkanlığı Teşkilatı Hakkında Cumhurbaşkanlığı Kararnamesi (2018). (1 SK, 10.07.2018). Resmi Gazete, (30474, 10.07.2018).

Ediger, M. (2001). Cooperative learning versus competition; Which is better? Educational Resources Information Center, 1-12. https://files.eric.ed.gov/fulltext/ED461894.pdf sayfasından erişilmiştir.

Erkılıç, T. A. (2013). Eğitim felsefeleri açısından köy enstitüleri. Dicle Üniversitesi Sosyal Bilimler Enstitüsü Dergisi, 5(9), 1-19.

Gilbert, P., McEwan, K., Bellew, R., Mills, A., and Gale, C. (2009). The dark side of competition: How competitive behaviour and striving to avoid inferiority are linked to depression, anxiety, stres and self-harm. The British Phsycological Society, 82,123-136. http://doi:10.1348/147608308X379806.

Heinrich, A. (2014). The effects of competition in the k-12 school setting and its relationship to behavior modification. https://www.winona.edu/counselor education/Media/The_Effects_of_Competition_in_the_K-12_School_Setting__Spring_2014_Capstone.pdf sayfasından erişilmiştir.

Hilk, C. L. (2013). Effects of cooperative, competitive and individualistic learning structures on college student achievement and peer relationships: A series of meta-analyses (Doctoral Dissertation). http://hdl.handle.net/11299/155783 sayfasından erişilmiş̧ir.

Horney, K. (1997). Günümüzün nevrotik insanı. (A. E. Bagatur, Çev.). İstanbul: Mert.

İnal, K. (2008). Eğitim ve ideoloji. İstanbul: Kalkedon.

Johnson, D. W., Maruyama, G., Johnson, R., Nelson D., and Skon L. (1981). Effects of cooperative, competitive and individualistic goal structures on achievement: A meta-analysis. Psychological Bulletin, 89(1), 47-62. http://dx.doi.org/10.1037/0033-2909.89.1.47

Johnson D. W., and Johnson, R. T. (1982). Effects of cooperative, competitive and individualistic learning experiences on cross-ethnic interaction and friendships. The Journal of Social Psychology. 118(1). 47-58. https://doi.org/10.1080/00224545.1982.9924417 
Johnson D. W., and Johnson, R. T. (1984). The effects of intergroup cooperation and intergroup competition on ingroup and outgroup cross-handicap relationships. The Journal of Social Psychology. 124(1), 85-94. https://doi.org/10.1080/00224545.1984.9924540

Johnson D. W., and Johnson, R. T. (1985). Relationships between black and white students in intergroup cooperation and competition. The Journal of Social Psychology. 125(4), 421-428. https://doi.org/10.1080/00224545.1985.9713521

Johnson D. W., and Johnson, R. T. (2017, September). Cooperative learning. Paper presented in Inovacion Educacion I. Congresso Internacional. https://2017.congresoinnovacion.educa.aragon.es/documents/48/David_Johnso n.pdf sayfasından erişilmiştir.

Johnson, R. T., Johnson D. W., and Stanne M. B. (1985). Effects of cooperative and individualistic goal structures on computer assisted instruction. Journal of Educational Psychology, 77(6), 668-677. http://dx.doi.org/10.1037/00220663.77.6.668

Kalowole, E. B. (2007). Effects of competitive and cooperative learning strategies on academic performance of Nigerian students in mathematics. Educational Research and Review. 3(1), 33-37.

Karasar, N. (2016). Bilimsel araştırma yöntemi. Kavramlar ilkeler teknikler. (31. bas.) Ankara: Nobel Yayıncılık.

Keskin, D. (2012). Bitmeyen sınavlar, yaşanmayan hayatlar. Eğitimde paradigma değişimi. (1. bas.) Ankara: Dipnot Yayınları

Kohn, A. (1992). No contest: The case against competition. Boston New York: Houghton Mifflin.

Köroğlu, A. (2008). Lise ögrencilerinin mükemmeliyetçi özellikleri ile rekabetçi tutumları arasındaki ilişkinin incelenmesi. (Yayımlanmamış yüksek lisans tezi). https://tez.yok.gov.tr/UlusalTezMerkezi/ sayfasından erişilmiştir (Tez No. 231791).

Ladd, H. F., and Fiske, E. B. (2003). Does competition improve teaching and learning? Evidence from New Zeland. Educational Evaluation and Policy Analysis, 25(1), 97-112.

Malkoç, A. ve Erginsoy, D. (2012). Rekabetçi tutum, bilişsel çarpıtmalar ve çok boyutlu kıskançlık. Psikoloji Çalışmalarl/ Studies in Psychology, 28, 1-14. http://dergipark.gov.tr/iupcd/issue/9405/117911 sayfasından erişilmiştir.

Mincemoyer, C. (1994). Cooperation, competition, and kids. https://extension.psu.edu/programs/4h/members/projectsresources/healthylifee d/cooperation-competition-and-kids/CompetSelfEsteem.pdf. sayfasindan erişilmiştir. 
Okçabol, R. (2007). Küreselleşme ve eğitim. E. Oğuz ve A. Yakar (Eds.) Küreselleşme ve eğitim içinde (ss. 141-163). Ankara: Dipnot.

Shindler, J. (2009). Transformative classroom management. San Francisco: Jossey Bass A Willey Imprint.

Skon, L. Johnson, D. W., and Johnson, R. T. (1981). Cooperative peer interaction versus individual competition and individualistic efforts: Effects on the acquisition of cognitive reasoning strategies. Journal of Educational Psychology. 73(1), 83-92.

Sönmez, V. (2019). Eğitim felsefesi. Ankara: Anı.

Sözer, E. (2008). Eğitimin felsefi temelleri. Gültekin, M. (Ed.), Eğitim bilimine giriş içinde (ss. 57-75). Eskişehir: Web.

Thousand, J., Villa, A., and Nevin, A. (1994). Creativity and Collaborative Learning. Baltimore: Brookes Press.

Türk Dil Kurumu (2019). Türkçe sözlük. Ankara: TDK.

Üresin, B. (2012). Beden eğitimi derslerinde uygulanan bireysel rekabetçi ve işbirlikli hedef yönelimlerinin ilkögretim 2. kademesinde okuyan öğrencilerin beden eğitimi derslerine yönelik tutumlarına etkisi. (Yayımlanmamış yüksek lisans tezi). https://tez.yok.gov.tr/UlusalTezMerkezi/ sayfasından erişilmiştir (Tez No. 326345).

Verhoeff, T. (1997). The role of competitions in education. Future World: Educating For The 21st Century. https:// pdfs.semanticscholar.org/6f2c/fcc7123ec0dffe3f745107c3f4cb5233f552.pdf sayfasından erişilmiş̧ir.

Yenidünya, A. (2005). Lise ögrencilerinde rekabetçi tutum, benlik saygısı ve akademik başarı iliş̧kisi. (Yayımlanmamış yüksek lisans tezi) https://tez.yok.gov.tr/UlusalTezMerkezi/ sayfasından erişilmiştir. (Tez No. 189026).

Yılmaz, M. T. (2014). Obez benlik: Narsisizm. Eleştirel Pedagoji, 6(35), 55-65.

Zhao, X. (2015). Competition and compassion in Chinese secondary education. New York: Palgrave Macmillan. 


\title{
Opinions of Primary School Teachers Regarding the Competition Among Students ${ }^{1}$
}

\begin{tabular}{cccc}
\hline ARTICLE TYPE & Received Date & Accepted Date & Published Date \\
Research Article & 02.08 .2021 & 08.21 .2021 & 10.07 .2021 \\
\hline
\end{tabular}

\author{
Merve Kurumanoğlu \\ National Education Ministry
}

Naciye Aksoy

Gazi University

\begin{abstract}
This research was carried out to determine the opinions of classroom teachers about the effects of competition on students in educational practices. The opinions of the teachers were analyzed according to their gender, length of service, type of school they work in (state-private), graduation level (undergraduate-graduate) and the grade level they teach. The research was designed according to a quantitative research approach and carried out in a descriptive survey model. The sample of the study consisted of 325 classroom teachers working in private and public primary schools in Yenimahalle district of Ankara. The teachers agree with the majority of the judgments about competition among students at a moderate level, and above the middle in the negative psycho-social effects (jealousy, stress, anxiety, pressure, negative self-esteem) that competition will create on students. Teachers working in private schools are more involved in the negative emotional/mental effects of competition on students, and teachers working in public schools are more likely to participate in the positive effects of competition on the educational process. Less senior teachers participated more in the negative effects of competition than high senior teachers. Gender, graduation level and the grade level taught are also determinants of teachers' participation in some judgments regarding competition among students.
\end{abstract}

Keywords: Competition among students, primary school, classroom teacher, neoliberalism, competitive education system.

Ethical comittee approval: Since this research was conducted before 01.01.2020, it does not require an ethics comittee decision.

\footnotetext{
${ }^{1}$ This study is derived from the master's thesis completed by the first author under the supervision of the second author at Gazi University, Institute of Educational Sciences in 2019.

${ }^{2}$ Corresponding Author: Ministry of Education Primary School Teacher. Gazi University Faculty of Education, Class Education, Primary Education Department, e-mail: mervekurumanoglu.12@gmail.com,https://orcid.org/0000-0003-4421-293X

${ }^{3}$ Prof. Dr. Gazi University Faculty of Education, Class Education, Primary Education Department, e-mail: naciyeksy@gmail.com, https://orcid.org/0000-0002-3136-6473
} 


\section{Purpose and Significance}

In a school environment where academic and social fields are intertwined, there is competition among students in many situations (Heinrich, 2014). Educational theorists and psychologists have different views on the advantages and disadvantages of competition. Some argue that competition is beneficial, while others argue that it is harmful. Some theorists think it is both beneficial and harmful. There are plenty of international studies on competition but a few in national literature. Also, no research directly addressing teachers' views on competition among students in schools has been found in the literature. Thus, the study aims to determine the perspectives of classroom teachers working in public and private primary schools on competition among students. Based on this general purpose, the research aims to answer the following questions:

1. What are the opinions of primary school teachers about competition among students?

2. Does the opinions of primary school teachers about competition among students vary according to
a. their gender,
b. the type of school they serve,
c. education level (undergraduate, graduate),
d. seniority (total year of service),
e. and grade levels they teach?

As explained in the conceptual framework, there is no consensus on competition due to the positive and negative effects of it. However, studies reveal that competition leads to destructive results in education and training processes and practices. Competition has become an indispensable reality in the Turkish education system. Although the complaints/concerns about this reality are constantly expressed by trade unions, academics, families, students and teachers, the number of studies on the subject is very limited. However, a healthy solution to a social problem is only possible with scientific data based on the participation of those who are parties to the issue. From this point of view, it is thought that taking the opinions of teachers, which is the most important component of the education system, on the relations between students and the competition, will make a significant contribution to the field. Thoughts determine behavior. Thus, it is expected that the results of this study will indirectly give clues about how teachers support or not support competition among students in their classroom practices.

\section{Method}

This research was designed as a quantitative research and carried out according to a descriptive survey model. The opinions of the classroom teachers in the sample on the competition between students were described as they exist, and there was no intervention in the teachers' views. Whether teachers' views on competition among students differ according to gender, seniority, school type, grade level, and 
educational status was also examined descriptively. The sample of the study consisted of 325 teachers. The opinions of teachers about the competition among students were obtained by the data collection tool developed by the researchers. Validity and reliability studies were conducted with a total of 130 questionnaires for the pilot study. In this study, statistical analyzes were performed by using percentage (\%), frequency $(\mathrm{N})$, arithmetic mean, standard deviation, $\mathrm{t}$ test and ANOVA.

\section{Results}

The opinions of classroom teachers on competition among students were evaluated over 50 judgments. Teachers "'Competition causes anxiety in students" $(\overline{\mathrm{X}}=$ 3.58), "Some students cannot show their real performance (academically, physically, socially) due to the pressure created by competition" ( $\bar{X}=3.59)$, "Competitive classroom environment, slow paced students' self-esteem negatively" $(\overline{\mathrm{X}}=3.62)$, "Competition causes students to experience stress" $(\overline{\mathrm{X}}=3.63)$ Competition makes some students more popular" ( $\overline{\mathrm{X}}=3.65)$ and Jealousy emerges among students in a competitive learning environment" $(\bar{X}=3.77)$ participated in their judgments above the middle. In other words, teachers' level of disagreement with these judgments is below $15 \%$. On the other hand, $60 \%$ of the teachers do not agree with the judgments "I include my students in the competition processes due to the pressure from the school administration" ( $\overline{\mathrm{X}}=2.42)$ and "Competitive education practices cause students to make gender discrimination" ( $\overline{\mathrm{X}}=2.44)$. Teachers agree with the 42 judgments other than those discussed here at a moderate level (2.50 - 3.49 point range).

In the "Disadvantages of Competition" dimension, a significant difference was observed in the opinions of teachers (Public School $\bar{X}=3.04$, Private School $\bar{X}=3.44$, $\mathrm{p}<.05)$ according to school type. Teachers working in private schools participate above the middle in 10 of 21 judgments in the Disadvantages of Competition dimension compared to teachers working in public schools. In general, the opinions of the teachers do not show a statistically significant difference according to gender, grade level, and educational level but differ in some judgments.

\section{Discussion and Conclusions}

Classroom teachers participated in 42 of 50 judgments regarding both positive and negative effects of competition between students at a moderate level. The fact that primary school teachers participate in $80 \%$ of the positive and negative judgments about the competition between students at a "moderate level" shows that teachers are not completely parties about the positive and negative aspects of competition. However, most of the teachers also participated above the middle in the negative psycho-social effects of competition on students. Teachers' participation in judgments such as "jealousy, negative self-perception, stress, anxiety, negative social relations created by competitive pressure" is an indication that they are aware of the negative aspects of competition. When the highest averages are examined, it can be said that classroom teachers have the opinion that competition increases the feeling of jealousy on students, the discrimination that comes with the desire to be popular, and the pressure and stress on them. 
Although the opinions of classroom teachers about competition among students did not show significance in terms of the "gender" variable, higher participation was observed in some judgments in the sub-dimensions of the scale compared to gender. Female teachers generally view competition more negatively than male teachers. However, female teachers also have contradictory views within themselves. Namely; while female teachers supported the judgments negating the competition, such as the polarization of the students among the students and causing stress and anxiety among the students, more than the male teachers. Both male and female teachers agree that competition is an approach that destroys the sense of equality and justice among students.

The school type (state-private) variable is determinant in teachers' views on competition among students. In general, teachers working in private schools are less supportive of competition among students than their colleagues working in public schools. Teachers working in private schools think that students are affected more negatively in terms of values such as "sharing, equality and justice, social solidarity, trust, quality of learning, solidarity, friendship relations", especially in the negative effects of competition, compared to teachers working in public schools. Private school teachers participated more in the judgments that competition would lead to negative effects such as "losing-shame, losing-worthlessness, stress, peer bullying, violence, deriving stereotypes against friends, lying, cheating". This result suggests that private schools operating under market conditions (Aksoy, Deniz, and Algan, 2017), with financial gain in the foreground, suggest that this result may be related to the competition to attract students among themselves and, accordingly, to put more pressure on both teachers and students to be successful. Private schools are therefore competitive institutions in terms of functioning. On the other hand, teachers working in public schools believe that it will not be possible to evaluate students fairly in noncompetitive educational practices, the quality of education will decrease and students' individual efforts will be wasted. Exams have become a norm in the Turkish education system, especially since the 1980s, and they are seen as the most rational and egalitarian tool for measuring student achievement (İnal, 2008).

Teachers who have an undergradute degree are more likely to agree that competition will cause peer bullying and anxiety on the one hand and that intergroup competition will enable them to cooperate among group members, on the other hand. Undergraduate teachers may hold the view that intergroup competition will contribute positively, despite the negative effects of competition on students. As a matter of fact, it is stated in the literature that a well-organized competition between teams improves students' learning skills (Cantador and Bellogin, 2012; Thousand, Villa, and Nevin, 1994).

The opinions of the teachers show significance in a few items in terms of the "seniority (service time)" variable. Teachers with seniority of 0-10 years are more aware of disadvantages such as competition destroys equality and justice among students, competition negatively affects the self-esteem of slow-paced students, fear 
of losing in a competitive environment leads to low performance, students create stereotypes against each other.

New studies to be done to determine the source of these differences will provide different perspectives on the subject. Supporting new studies in the field with in-class observations and interviews will enable students to demonstrate their behavior and attitudes towards competition as the subject of education. Studies on how competition between students affect the acquisition of values such as cooperation, respect, sharing, and solidarity will also provide scientific data to decision mechanisms in reviewing the aims, content, learning-teaching methods and measurement and evaluation processes of education.

\section{Ethical Comittee Approval}

Since this research was conducted before 01.01.2020, it does not require an ethics comittee decision. 